Jennings, H. J., Katzenellenbogen, E., Rosell, K.-G., \& Kasper, D. L. (1983) J. Biol. Chem. (in press).

Kane, J. A., \& Karakawa, W. W. (1978) Infect. Immun. 19, 983.

Kasper, D. L., Baker, C. J., Baltimore, R. S., Crabb, J. H., Schiffman, G., \& Jennings, H. J. (1979) J. Exp. Med. 149, 327.

Kenne, L., \& Lindberg, B. (1980) Methods Carbohydr. Chem. $8,295$.

Lancefield, R. C. (1933) J. Exp. Med. 57, 571.

Lancefield, R. C. (1934) J. Exp. Med. 59, 441.

Lancefield, R. C. (1938) J. Exp. Med. 67, 25.

Lancefield, R. C., \& Freimer, E. H. (1966) J. Hyg. 64, 191.

Leontein, K., Lindberg, B., \& Lonngren, J. (1978) Carbohydr. Res. 62, 359.
Lindberg, B. (1972) Methods Enzymol. 28B, 178.

Russell, H., \& Norcross, N. L. (1972) J. Immunol. 109, 90.

Sadler, J. E., Paulson, J. C., \& Hill, R. L. (1979) J. Biol. Chem. 254, 2112.

Sawardeker, J. S., Sloneker, J. H., \& Jeanes, A. R. (1965) Anal. Chem. 37, 1602.

Spiro,.R. G., \& Bhoyroo, V. D. (1974) J. Biol. Chem. 249, 5704.

Stellner, K., Saito, H., \& Hakamori, S. (1973) Arch. Biochem. Biophys. 155, 464.

Tai, J. Y., Gotschlich, E. C., \& Lancefield, R. C. (1979) J. Exp. Med. 149, 58.

Terleckyj, B., Willett, N. P., \& Schockman, G. D. (1975) Infect. Immun. 11, 649.

Wilkinson, H. W., \& Eagon, H. (1971) Infect. Immun. 4, 596.

\title{
Unexpected Similarity of the Structures of the Weakly Toxic Amanitin $(S)$-Sulfoxide and the Highly Toxic $(R)$-Sulfoxide and Sulfone As Revealed by Proton Nuclear Magnetic Resonance and X-ray Analysis ${ }^{\dagger}$
}

\author{
Theodor Wieland," Christa Götzendörfer, Janusz Dabrowski, William N. Lipscomb, and Gil Shoham
}

ABSTRACT: The three-dimensional structures of the slightly toxic diastereomeric $(S)$-sulfoxide of $6^{\prime}$ - $O$-methyl- $\alpha$-amanitin $\left[6^{\prime}-O-\mathrm{Me}-\alpha\right.$-ama $(S)$-sulfoxide, 4$]$ and of the corresponding highly toxic sulfone 5 have been determined by X-ray diffraction analysis. The same derivatives along with 6 - $O$ methyl- $\alpha$-amanitin [O-Me- $\alpha$-ama $(R)$-sulfoxide, 3 ] and the corresponding thioether ( $O$-Me- $\alpha$-ama sulfide, 6 ) have been investigated in dimethyl sulfoxide solutions by $360-\mathrm{MHz}{ }^{1} \mathrm{H}$ NMR spectroscopy including nuclear Overhauser effects (NOE). In addition $\alpha$-amanitin (2) has been reinvestigated by this high-resolution method involving the identification of the ABMX systems of the tryptophan, cysteine, and asparagine and discrimination between the glycine residues. The structures of compounds 2-6 are compared with the structure of $\beta$-amanitin which was solved previously by $\mathrm{X}$-ray structure analysis. The results are (1) the structures in the crystalline

$\mathbf{I}_{1}$ 1941 Wieland et al. (1941) reported on the isolation from the toxic mushroom Amanita phalloides of the slow-acting toxin and called it amanitin. Many years later this component was recognized as a mixture of a neutral compound, called $\alpha$-amanitin, and an acidic one, $\beta$-amanitin (Wieland et al., 1949). Later on $\beta$-amanitin was found to be the carboxylic acid (1) whose carboxamide derivative represents $\alpha$-amanitin (2) (Wieland \& Boehringer, 1960). The three-dimensional structure of 1 in the solid state was determined by X-ray diffraction analysis (Kostansek et al., 1977, 1978) whereas a three-dimensional structure of 2 was suggested from NMR

\footnotetext{
${ }^{\dagger}$ From the Max-Planck-Institut für medizinische Forschung, Abteilung Naturstoffchemie (Th.W. and Ch.G.) and Organische Chemie (J.D.), D-6900 Heidelberg, West Germany, and Department of Chemistry (W.N.L. and G.S.), Harvard University, Cambridge, Massachusetts 02138. Received August 13,1982. Publication No. 60 on Components of the Green Deathcap Mushroom (Amanita phalloides). For No. 59, see Wieland et al. (1981). The research at Harvard University was supported by Grant GM 06920 from the National Institutes of Health.
}

state of the $(S)$-sulfoxide 4 and sulfone 5 are practically identical and (2) in dimethyl sulfoxide solution the structures of compounds $\mathbf{4}$ and $\mathbf{5}$ are likewise identical with each other and with those of the $(R)$-sulfoxide 3 and the thioether 6 . The general structure of the peptide backbone of the $\alpha$-amanitin derivatives investigated here almost corresponds to that of $\beta$-amanitin (1), the main difference being a rotated plane of the peptide bond between the asparagine and cysteine residue. In order to explain the lack of high toxicity in the $(S)$-sulfoxide 4 we tentatively suggest alternative hydrogen bonding of a donor from the protein, or displacement of the $R$ oxygen to the $S$ oxygen of a hydrogen bond donor. This alternative bonding or displacement might not occur in the sulfoxide 4. Other explanations which include local conformational changes in the inhibitors or a difference between the $\mathrm{SO}$ and $\mathrm{SO}_{2}$ local dipoles are also possible.

data by Tonelli et al. (1978). There is rather good agreement between the crystal structure of $\mathbf{1}$ and the solution structure of 2.

Compounds 1 and 2 are $(R)$-sulfoxides (Faulstich et al., $1968)$. The question arose as to whether the $(R)$-sulfoxide moiety of the amatoxins is a structural feature essential for their toxicity. Hence, the modification of this structural element was undertaken. The sulfoxide oxygen atom of $6^{\prime}-O$ methyl- $\alpha$-amanitin (3), an equally toxic derivative of 2 , was removed by treatment either with Raney nickel (Buku et al., 1974) or with $\mathrm{K}_{3} \mathrm{MoCl}_{6}$ [according to Nuzzo et al. (1977); A. Buku, unpublished results]. Reoxidation of the thioether 6 yielded the $(R)$-sulfoxide 3 along with the diastereomeric $(S)$-sulfoxide 4 and the sulfone 5 (Buku et al., 1974). The formulas of the amatoxins mentioned are given in Figure 1 and in Table I.

Interestingly, thioether $\mathbf{6}$ and sulfone 5 show high toxicity like the $(R)$-sulfoxides $1-3$, whereas the $(S)$-sulfoxide 4 is at least 20 times less toxic. The inhibitory constants of DNA- 


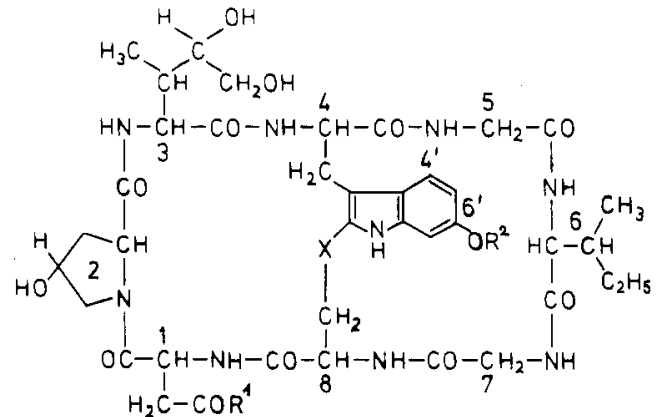

FIGURE 1: General formula of the amatoxins mentioned in this paper. For the meanings of the symbols $R^{1}, R^{2}$, and $X$ see in Table $I$. The numbering $4^{\prime}$ and $6^{\prime}$ (IUPAC) corresponds to 5 and 7 , respectively, in the system used in X-ray analysis (Figure S1 in supplementary material).

\begin{tabular}{|c|c|c|c|c|}
\hline no. & $\mathrm{R}^{1}$ & $\mathrm{R}^{2}$ & $X$ & name \\
\hline $\begin{array}{l}1 \\
2 \\
3 \\
4 \\
5 \\
6\end{array}$ & $\begin{array}{l}\mathrm{OH} \\
\mathrm{NH}_{2} \\
\mathrm{NH}_{2} \\
\mathrm{NH}_{2} \\
\mathrm{NH}_{2} \\
\mathrm{NH}_{2}\end{array}$ & $\begin{array}{l}\mathrm{H} \\
\mathrm{H} \\
\mathrm{CH}_{3} \\
\mathrm{CH}_{3} \\
\mathrm{CH}_{3} \\
\mathrm{CH}_{3}\end{array}$ & $\begin{array}{l}\mathrm{SO}(R) \\
\mathrm{SO}(R) \\
\mathrm{SO}(R) \\
\mathrm{SO}(S) \\
\mathrm{SO}_{2} \\
\mathrm{~S}\end{array}$ & $\begin{array}{l}\beta \text {-amanitin [ } \beta \text {-ama }(R) \text {-sulfoxide] }{ }^{b} \\
\alpha \text {-amanitin }[\alpha \text {-ama }(R) \text {-sulfoxide] } \\
O \text {-Me- } \alpha \text {-ama }(R) \text {-sulfoxide } \\
O \text {-Me- } \alpha \text {-ama }(S) \text {-sulfoxide } \\
O \text {-Me- } \alpha \text {-ama sulfone } \\
O \text {-Me- } \alpha \text {-ama sulfide }\end{array}$ \\
\hline
\end{tabular}

${ }^{a}$ The symbols $\mathrm{R}^{1}, \mathrm{R}^{2}$, and $\mathrm{X}$ refer to the formula of Figure 1 .

$b$ This nomenclature refers to the different states of the sulfur bridge in the compounds investigated.

dependent RNA polymerase II (or B) from calf thymus are small $\left(K_{\mathrm{i}}=2.5-5.0 \mathrm{nM}\right.$ ) for the highly toxic compounds 1 , $2,3,5$, and 6 , but 4 exhibits a $K_{\mathrm{i}}=20 \mathrm{nM}$ (Wieland et al., 1981).

In order to understand the striking differences in toxicity of $(S)$-sulfoxide 4 and sulfone 5 , both of which contain an oxygen atom at the same side of the sulfur atom, it was at first supposed that 4 and 5 would have different conformations. Therefore, the conformations of these compounds were determined in $\mathrm{Me}_{2} \mathrm{SO}^{1}$ solution by NMR spectroscopy and in crystals by $\mathrm{X}$-ray diffraction analysis. The structures obtained were compared with those of $\beta$-amanitin (1) which has been solved previously (Kostansek et al., 1978) and $\alpha$-amanitin (2) (Tonelli et al., 1978), as well as with the solution structures of 3 and of thioether 6 described in this paper. The application of modern NMR techniques at $360 \mathrm{MHz}$ enabled us to resolve certain ambiguities in the spectral assignments concerning compound 2, which was investigated previously with comparatively low spectral resolution at $220 \mathrm{MHz}$ (Tonelli et al., 1978). Thus, the essential problem of differentiation between the formally identical ABMX spin systems of the tryptophan, cysteine, and asparagine residues, $\mathrm{HNC}^{\alpha} \mathrm{HC}^{\beta} \mathrm{H}_{2}$, and between the ABX systems of the glycines in positions 5 and 7, was solved by using NOE $^{1}$ difference spectroscopy and by using data on the shielding effect of the sulfoxide and sulfone group. The same procedure was applied in compounds 2,3 , and 6 .

\section{Materials and Methods}

Amatoxins. The derivatives of $\alpha$-amanitin (3-6) were obtained by methylation of 2 with diazomethane and deoxygenation of the $(R)$-sulfoxide moiety by boiling with Raney nickel (Buku et al., 1974) or with $\mathrm{K}_{3} \mathrm{MoCl}_{6}$ (Nuzzo et al., 1977). The thioether 6 so formed was oxidized with $\mathrm{H}_{2} \mathrm{O}_{2}$ in acetic acid to yield a mixture of 3-5 which was separated by

1 Abbreviations: NOE, nuclear Overhauser enhancement, or effect; SDDS, scalar-decoupling difference spectroscopy; $\mathrm{Me}_{2} \mathrm{SO}$, dimethyl sulfoxide; $\mathrm{Me}_{4} \mathrm{Si}$, tetramethylsilane; $\mathrm{Hyi}, \gamma, \delta$-dihydroxyisoleucine. chromatography. Crystallization in $90 \%$ ethanol yielded crystals of 5 which were suitable for X-ray structure analysis. Unfortunately, 6 crystallized in extremely thin needles, and 3 did not crystallize even though it was pure as determined by thin-layer chromatography and ultraviolet spectroscopy.

$X$-ray Structure Analysis. The crystal structure of sulfone 5 was determined from crystals which were grown from $90 / 10$ ethanol/water solution. Extinctions indicated that the space group is $P 2_{1} 2_{1} 2_{1}$. The unit cell, which has the dimensions $a$ $=16.123$ (3), $b=18.358$ (4), and $c=20.119$ (5) $\AA$, contains four molecules of the cyclic peptide, and solvent molecules as described below. The X-ray diffraction data were collected from a single crystal $(0.7 \times 0.7 \times 0.3 \mathrm{~mm})$, which had been sealed in a glass capillary along with a small amount of mother liquor in order to prevent deterioration. Integrated intensities of 5490 independent reflections in the range $3^{\circ} \leq 2 \theta \leq 130^{\circ}$ were measured in the $\theta / 2 \theta$ mode with the use of $\mathrm{Cu} \mathrm{K} \alpha$ radiation, graphite monochromated, on an automated four-circle Syntex $P 2_{1}$ diffractometer. Corrections were applied for Lorentz and polarization factors and, empirically, for absorption effects. The sulfur and five non-hydrogen atoms were found by direct methods using MULTAN-78 (Main et al., 1978), and all remaining non-hydrogen atoms were then located in difference electron density maps.

Refinement, including anisotropic thermal parameters for all non-hydrogen atoms, was carried out by use of block-diagonal least-squares methods (Sheldrick, 1975). Statistical occupancies of $0.27-1.0$ for four water molecules and of 0.33-1.0 for four ethanol molecules were found from difference maps of the asymmetric unit, i.e., one-fourth of the unit cell. Those 4388 reflections having values of $F_{0} \geq 4 \sigma\left(F_{0}\right)$ led, upon refinement of the structure, to a value of $R=0.076$ ( $R=$ $\left.\sum\left\|F_{\mathrm{o}}|-| F_{\mathrm{c}}\right\| / \sum\left|F_{\mathrm{o}}\right|\right)$ when all non-hydrogen atoms were included. Final atomic parameter shifts were less than 0.1 times their standard deviations, and no peaks higher than $0.4 \mathrm{e} / \AA^{3}$ were seen in the final difference electron density map.

The crystal structure of the $(S)$-sulfoxide 4 was solved from crystals which were grown from a methanol solution. The space group is $P 2_{1} 2_{1} 2_{1}$, and unit cell dimensions are $a=15.883$ (2), $b=18.245(2)$, and $c=20.247$ (3) $\AA$. The diffraction data were taken from a single crystal of dimensions $0.8 \times 0.5$ $\times 0.3 \mathrm{~mm}$ which had been sealed into a glass capillary along with mother liquor. Of the 5423 independent reflections in the range $3^{\circ} \leq 2 \theta \leq 130^{\circ}$, those 4666 for which $F_{0} \geq 4 \sigma\left(F_{0}\right)$ were included in the refinement. While the sulfur atom was located in the Patterson function, successive difference electron density maps did not reveal the structure. Use of direct methods (Main et al., 1978) confirmed these sulfur positions and located in addition 11 non-hydrogen atoms. The remainder of the structure was then found from cycles of difference electron density maps and block-diagonal least-squares refinements (Sheldrick, 1975). Also, six methanol molecules and one water molecule were found in the asymmetric unit. Except for one methanol molecule which has an occupancy of 0.25 , all solvent molecules showed full occupancy. Hydrogen atoms were not included in these final refinements, which led to $R=0.075$ when anisotropic thermal parameters were included. The final atomic parameter shifts were less than 0.03 times their standard deviations, and the largest peak in the final difference electron density was less than $0.45 \mathrm{e} / \AA^{3}$.

NMR Measurements. Samples were dried at $2 \times 10^{-6}$ torr and dissolved in $\mathrm{Me}_{2} \mathrm{SO}-d_{6}$ containing $\mathrm{Me}_{4} \mathrm{Si}$, yielding $3 \%$ solutions which were repeatedly degassed and sealed under helium. The $360-\mathrm{MHz}^{1} \mathrm{H}$ NMR spectra were obtained at $313 \mathrm{~K}$ on a Bruker HX-360 spectrometer using $16 \mathrm{~K}$ data 

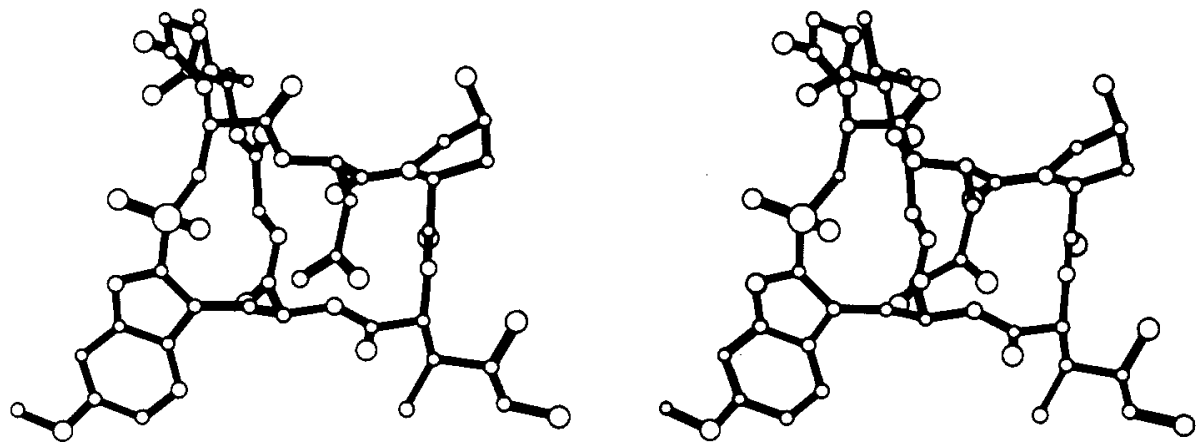

FIGURE 2: Stereoview of molecule 5.
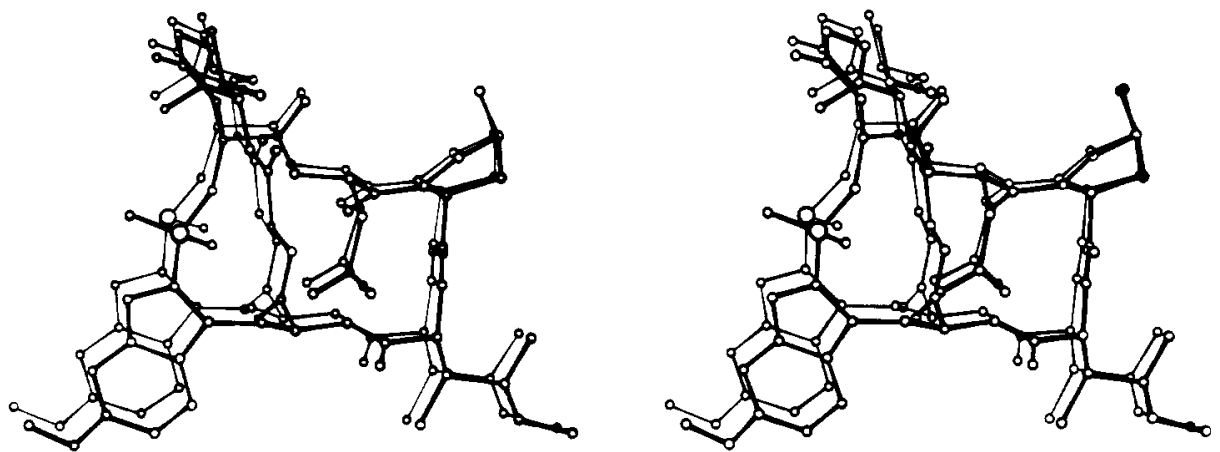

FIGURE 3: Stereoview of molecule 4 (thin line) superimposed on stereoview of molecule 5 (thick line).
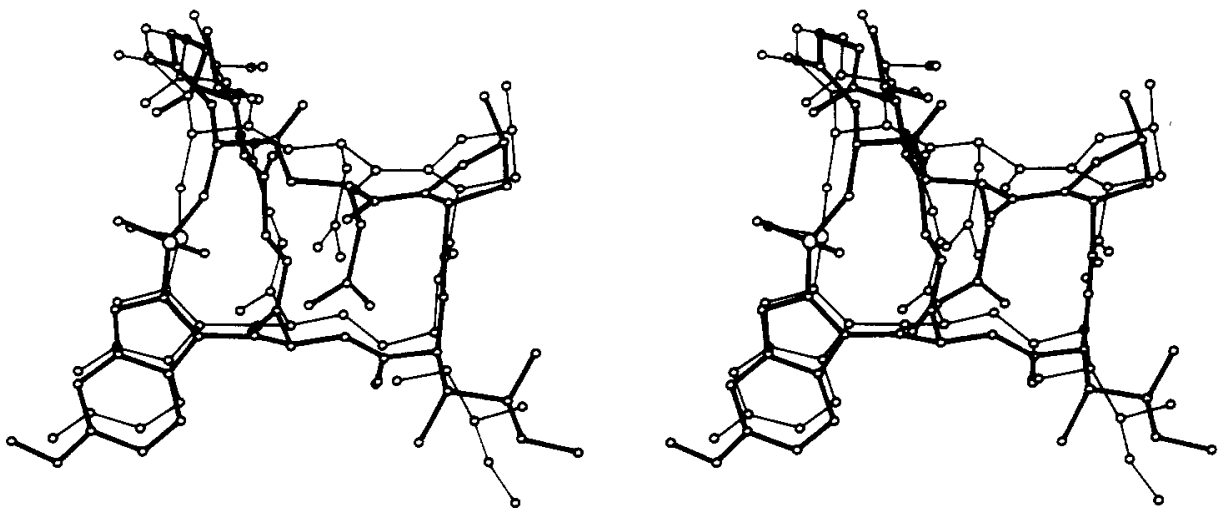

FIGURE 4: Stereoview of $\beta$-amanitin (Kostansek et al., 1978) (thin line) superimposed on stereoview of molecule 5 (thick line).

points of the Aspect 2000 computer for $4.5-\mathrm{kHz}$ spectral width. The free induction decays were multiplied by a resolutionenhancement function (Ernst, 1966) included into the Bruker software package. Overlapping signals were singled out with the aid of SDDS (Gibbons et al., 1975). The NOE and spin-decoupled NOE difference spectra were measured in the manner described by Wagner \& Wüthrich (1979) and Richarz \& Wüthrich (1978), respectively.

\section{Results}

$X$-ray Structure Analysis. Stereoview of sulfone 5 is shown in Figure 2, and in Figure 3 a stereoview is given in which molecule 4 is superimposed on molecule 5 for comparison. Detailed structural parameters are presented in the supplementary material (see paragraph at end of paper regarding supplementary material).

Although there are significant differences in toxicity and binding of compounds 4 and 5 (Buku et al., 1974; Wieland \& Faulstich, 1978; Wieland et al., 1981), the conformation differences (Figure 3 ) are unexpectedly small.

The best fit of 4 and 5 by least-squares rotation methods (Kabsch, 1976, 1978) gives root mean square deviation of 0.1 $\AA$ between the related atoms in the structures. The major difference is, of course, the extra oxygen in the $R$ configuration in the sulfone group of 5 .

In both 4 and 5 the two cyclic segments of the chain are approximately perpendicular to each other, and there is a short segment, Ile ${ }^{6}-$ Gly $^{7}$, which is almost part of an $\alpha$ helix. All peptide bonds are in the trans conformation. The overall shape is generally similar to that of $\beta$-amanitin (1) (Kostansek et al., 1978), except that the side chains are somewhat more compact (Figure 4) and the plane of the peptide bond between asparagine and cysteine is rotated by about $90^{\circ}$. This rotation is probably due to the hydrogen bond between the $\mathrm{NH}$ group of asparagine and the $S$ oxygen on the sulfur in 4 and 5 . In addition, in $\beta$-amanitin a weak hydrogen bond $(3.2 \AA)$ exists between the NH group of Asp ${ }^{1}$ and the carbonyl oxygen of Gly.

The five intramolecular hydrogen bonds, all less than 3.0 $\AA$ in length, appear to dominate the secondary structure. Since there are no strong intermolecular contacts, it can be anticipated that the conformation will be the same in solution as it is in the crystal. This conclusion is further supported by the similar conformations of $\mathbf{4}$ and $\mathbf{5}$ in their crystal structures in spite of substantial differences in the interactions of solvent with these cyclic peptide molecules. 

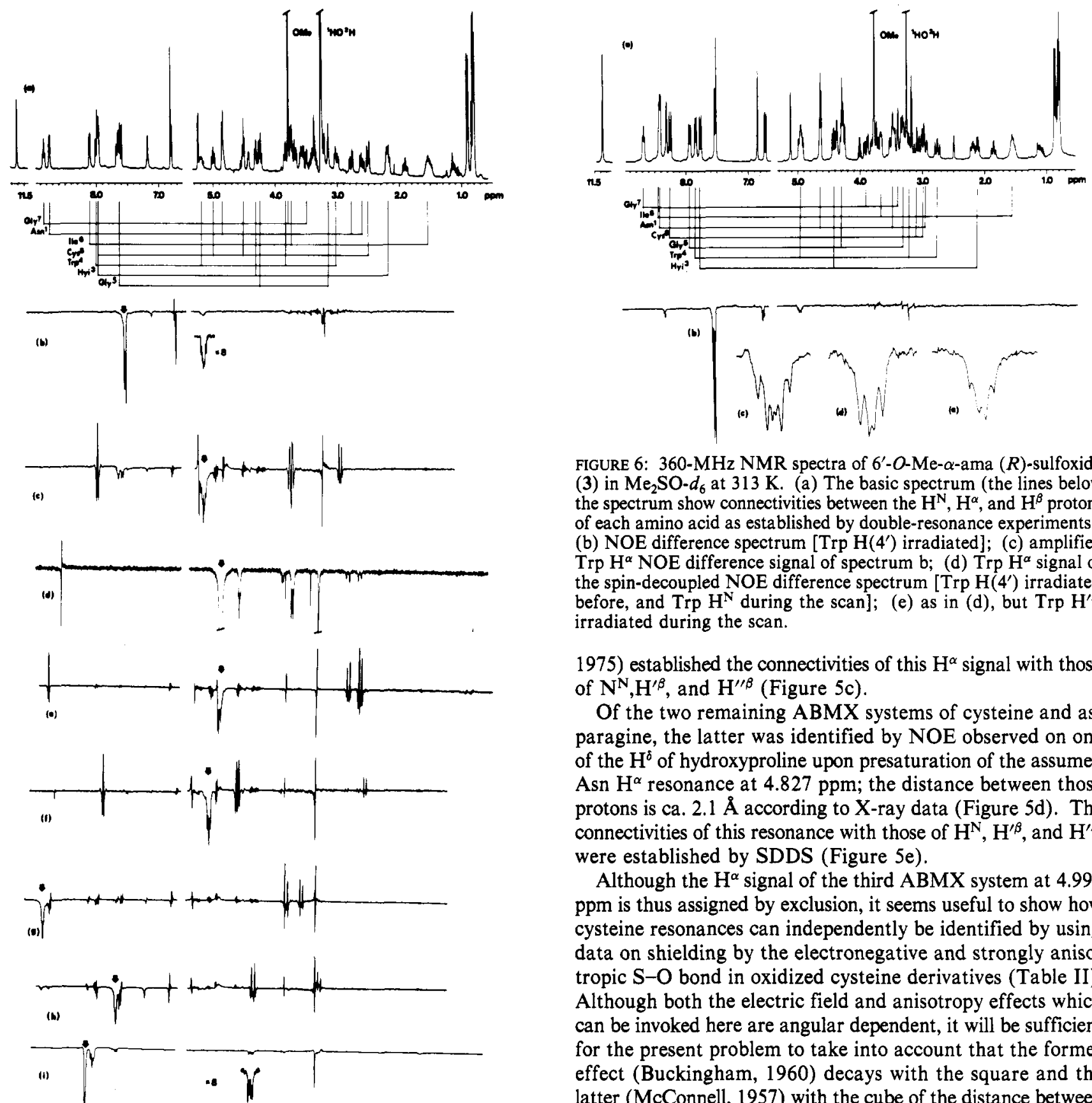

FIGURE 5: $360-\mathrm{MHz}$ NMR spectra of 6'-O-Me- $\alpha$-ama (S)-sulfoxide (4) in $\mathrm{Me}, \mathrm{SO}-d_{6}$ at $313 \mathrm{~K}$. (a) The basic spectrum (the lines below the spectrum show connectivities between the $\mathrm{H}^{\mathrm{N}}, \mathrm{H}^{\alpha}$, and $\mathrm{H}^{\beta}$ protons of each amino acid as established by double-resonance experiments); (b, d, i) NOE difference spectra; (c, e-h) SDDS spectra; irradiation by a second radio-frequency field is indicated by arrows.

Proton NMR Spectroscopy. The assignments of all NMR signals of compounds 2-6 presented in Table II and illustrated for 3 and 4 in Figures 5a and 6a, respectively, were obtained as follows. The signals of the aromatic protons of tryptophan of $O$-Me- $\alpha$-ama $(S)$-sulfoxide (4) in $\mathrm{Me}_{2} \mathrm{SO}-d_{6}$ solution have been identified by spin decoupling. The through space distance between the ring $\mathrm{H}\left(4^{\prime}\right)$ and $\operatorname{Trp} \mathrm{H}^{\alpha}$ depends on conformation but can be as small as ca. $1.9 \AA$, thus providing a possible basis for the identification of the latter by NOE measurements. The NOE difference spectrum obtained by irradiation of the doublet of $\operatorname{Trp~} \mathrm{H}\left(4^{\prime}\right)$ at $7.603 \mathrm{ppm}$ (Figure 5b) shows a clean, strong, negative NOE signal at $5.192 \mathrm{ppm}$ which can thus unambiguously be assigned to $\operatorname{Trp} \mathrm{H}^{\alpha}$. Furthermore, the spin-decoupling difference spectrum (SDDS; Gibbons et al.,

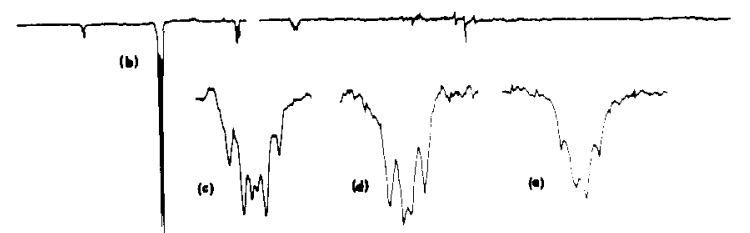

FIGURE 6: $360-\mathrm{MHz}$ NMR spectra of $6^{\prime}-O$-Me- $\alpha$-ama $(R)$-sulfoxide (3) in $\mathrm{Me}_{2} \mathrm{SO}-d_{6}$ at $313 \mathrm{~K}$. (a) The basic spectrum (the lines below the spectrum show connectivities between the $\mathrm{H}^{\mathrm{N}}, \mathrm{H}^{\alpha}$, and $\mathrm{H}^{\beta}$ protons of each amino acid as established by double-resonance experiments); (b) NOE difference spectrum [Trp H(4') irradiated]; (c) amplified Trp $\mathrm{H}^{\alpha}$ NOE difference signal of spectrum b; (d) Trp $\mathrm{H}^{\alpha}$ signal of the spin-decoupled NOE difference spectrum [Trp $H\left(4^{\prime}\right)$ irradiated before, and $\operatorname{Trp} \mathrm{H}^{\mathrm{N}}$ during the scan]; (e) as in (d), but $\operatorname{Trp~} \mathrm{H}^{\prime \prime \beta}$ irradiated during the scan.

1975) established the connectivities of this $\mathrm{H}^{\alpha}$ signal with those of $\mathrm{N}^{\mathrm{N}}, \mathrm{H}^{\prime \beta}$, and $\mathrm{H}^{\prime \prime \beta}$ (Figure $5 \mathrm{c}$ ).

Of the two remaining ABMX systems of cysteine and asparagine, the latter was identified by NOE observed on one of the $\mathrm{H}^{\delta}$ of hydroxyproline upon presaturation of the assumed Asn $\mathrm{H}^{\alpha}$ resonance at $4.827 \mathrm{ppm}$; the distance between those protons is ca. $2.1 \AA$ according to $\mathrm{X}$-ray data (Figure $5 \mathrm{~d}$ ). The connectivities of this resonance with those of $\mathrm{H}^{\mathrm{N}}, \mathrm{H}^{\prime \beta}$, and $\mathrm{H}^{\prime \prime \beta}$ were established by SDDS (Figure 5e).

Although the $\mathrm{H}^{\alpha}$ signal of the third ABMX system at 4.993 ppm is thus assigned by exclusion, it seems useful to show how cysteine resonances can independently be identified by using data on shielding by the electronegative and strongly anisotropic S-O bond in oxidized cysteine derivatives (Table II). Although both the electric field and anisotropy effects which can be invoked here are angular dependent, it will be sufficient for the present problem to take into account that the former effect (Buckingham, 1960) decays with the square and the latter (McConnell, 1957) with the cube of the distance between the proton and the group under question. Accordingly, when going from the thioether 6 to the sulfoxide 4 one expects a larger shift for the resonance of $\mathrm{Cys} \mathrm{H}^{\alpha}$, which is ca. $3 \AA$ away from the $\mathrm{S}-\mathrm{O}$ bond, than for Asn $\mathrm{H}^{\alpha}$, which must be located considerably farther. Since the differential shift $\delta\left[\mathrm{H}^{\alpha}(\mathbf{4})\right]-$ $\delta\left[\mathrm{H}^{\alpha}(6)\right]$ amounts to $0.425 \mathrm{ppm}$ for one of those spin systems and only $0.110 \mathrm{ppm}$ for the other one, the former system is ascribed here to cysteine. Again, the connectivities for this system were found by SDDS (Figure 5f).

One of the two glycine ABX systems can immediately be recognized by the triplet $H^{N}$ signal at 8.851 ppm which can be correlated by decoupling experiments with the $\mathrm{H}^{\prime \alpha}$ and $\mathrm{H}^{\prime \prime \alpha}$ protons at 3.764 and $3.516 \mathrm{ppm}$, respectively (Figure $5 \mathrm{~g}$ ). The $\mathrm{H}^{\mathrm{N}}$ signal of the other glycine residue is a slightly broadened doublet (at $7.665 \mathrm{ppm}$ ), indicating that one of the ${ }^{3} J_{\mathrm{HNC}^{\alpha} \mathrm{H}}$ coupling constants is very small. This small coupling was resolved in the difference spectrum (Figure $5 \mathrm{~h}$ ). Since Gly and $\mathrm{Gly}^{7}$ differ strongly in their ${ }^{3} J_{\mathrm{HNC}^{\alpha} \mathrm{H}}$ coupling constants (Table II), it was important for the determination of the spatial structure of 4 in solution to differentiate between them. This 
Table II: Proton Chemical Shifts (ppm from $\mathrm{Me}_{4} \mathrm{Si}$ ) and Coupling Constants (Hz) of Amanitin Derivatives 2-6 in $\mathrm{Me}_{2} \mathrm{SO}-d_{6}$ at $313 \mathrm{~K}$

\begin{tabular}{|c|c|c|c|c|c|c|c|c|c|c|c|c|}
\hline \multirow{2}{*}{$\begin{array}{l}\text { amino } \\
\text { acid }\end{array}$} & \multirow[b]{2}{*}{ proton } & \multirow{2}{*}{$\begin{array}{l}\text { interproton } \\
\text { coupling }\end{array}$} & \multicolumn{2}{|l|}{2} & \multicolumn{2}{|c|}{3} & \multicolumn{2}{|c|}{4} & \multicolumn{2}{|c|}{5} & \multicolumn{2}{|c|}{6} \\
\hline & & & $\mathrm{ppm}$ & $J(\mathrm{~Hz})$ & $\mathrm{ppm}$ & $J(\mathrm{~Hz})$ & $\mathrm{ppm}$ & $J(\mathrm{~Hz})$ & $\mathrm{ppm}$ & $J(\overline{\mathrm{Hz}})$ & ppm & $J(\mathrm{~Hz})$ \\
\hline \multirow[t]{6}{*}{$\overline{A s n^{1}}$} & $\mathrm{HN}$ & $\mathrm{HNC}^{\alpha} \mathrm{H}$ & 8.411 & 2.2 & 8.418 & 2.2 & 8.754 & 5.5 & 8.315 & 3.9 & 8.395 & 3.8 \\
\hline & $\mathrm{HC}^{\alpha}$ & $\mathrm{HC}^{a} \mathrm{C}^{\beta} \mathrm{H}^{\prime}$ & 4.636 & 3.3 & 4.639 & 3.3 & 4.827 & 4.4 & 4.665 & 3.8 & 4.717 & 3.8 \\
\hline & $\mathrm{H}^{\prime} \mathrm{C}^{\beta}$ & $\mathrm{H}^{\prime} \mathrm{C}^{\beta} \mathrm{H}^{\prime \prime}$ & 3.5 & 17.0 & 3.5 & 17.0 & 2.769 & 15.4 & 3.306 & 17.0 & 3.333 & 15.0 \\
\hline & $\mathrm{H}^{\prime \prime} \mathrm{C}^{\beta}$ & $\mathrm{HC}^{\alpha} \mathrm{C}^{\beta} \mathrm{H}^{\prime \prime}$ & 2.950 & 4.0 & 2.950 & 4.0 & 2.616 & 8.2 & 2.921 & 5.0 & 2.939 & 4.4 \\
\hline & $\mathrm{NH}_{2}$ & & 8.317 & & 8.319 & & 7.647 & & 7.928 & & 8.044 & \\
\hline & & & 7.511 & & 7.519 & & 7.178 & & 7.278 & & 7.358 & \\
\hline \multirow[t]{7}{*}{ Hyp ${ }^{2}$} & $\mathrm{HC}^{\alpha}$ & & 4.278 & & 4.264 & & 4.222 & & 4.275 & & 4.297 & \\
\hline & $\mathrm{H}^{\prime} \mathrm{C}^{\beta}$ & & 2.189 & & 2.186 & & 2.208 & & 2.194 & & 2.208 & \\
\hline & $\mathrm{H}^{\prime \prime} \mathrm{C}^{\beta}$ & & 1.854 & & 1.853 & & 1.908 & & 1.882 & & 1.883 & \\
\hline & $\mathrm{HC}^{\gamma}$ & & 4.372 & & 4.372 & & 4.433 & & 4.389 & & 4.400 & \\
\hline & $\mathrm{H}^{\prime} \mathrm{C}^{\delta}$ & & 3.8 & & 3.8 & & 3.683 & & 3.792 & & 3.803 & \\
\hline & $\mathrm{H}^{\prime \prime} \mathrm{C}^{\delta}$ & & 3.0 & & 3.8 & & 3.578 & & 3.694 & & 3.722 & \\
\hline & $\mathrm{HO}$ & $\mathrm{HC}^{\delta} \mathrm{OH}^{\gamma}$ & 5.122 & 2.2 & 5.122 & 2.7 & 5.236 & 2.7 & 5.144 & & 5.178 & 2.7 \\
\hline \multirow[t]{8}{*}{$\mathrm{Hyi}^{3}$} & $\mathrm{HN}$ & $\mathrm{HNC}^{\alpha} \mathrm{H}$ & 7.775 & 9.9 & 7.771 & 9.4 & 7.967 & 7.7 & 7.814 & 8.8 & 7.928 & 9.3 \\
\hline & $\mathrm{HC}^{\alpha}$ & $\mathrm{HC}^{\alpha} \mathrm{C}^{\beta} \mathrm{H}^{\prime \prime}$ & 4.426 & 6.6 & 4.426 & 7.1 & 4.319 & 3.3 & 4.436 & 5.5 & 4.465 & 5.5 \\
\hline & $\mathrm{HC}^{\beta}$ & & 2.113 & & 2.114 & & 2.194 & & 2.167 & & 2.208 & \\
\hline & $\mathrm{HC}^{\gamma}$ & & 3.522 & & 3.5 & & 3.578 & & 3.5 & & 3.507 & \\
\hline & $\mathrm{H}^{\prime} \mathrm{C}^{\delta}$ & & 3.3 & & 3.3 & & 3.414 & & 3.250 & & 3.306 & \\
\hline & $\mathrm{H}^{\prime \prime} \mathrm{C}^{\delta}$ & & & & $1<10$ & & 3.356 & & 3.333 & & 3.444 & \\
\hline & $\mathrm{HOC}^{\gamma}$ & & $\begin{array}{l}4.636 \\
4.278\end{array}$ & & $\begin{array}{l}4.640 \\
4.290\end{array}$ & & 4.847 & & 4.764 & & 4.756 & \\
\hline & $\mathrm{HOC}^{\delta}$ & $\mathrm{HC}^{\beta} \mathrm{CH}$ & $\begin{array}{l}4.278 \\
0.867\end{array}$ & 6.6 & $\begin{array}{l}4.290 \\
0.870\end{array}$ & & 4.511 & & 4.333 & & 4.325 & \\
\hline \multirow[t]{9}{*}{$\operatorname{Trp} p^{4}$} & $\begin{array}{l}\mathrm{CH}_{3} \\
\mathrm{HN}\end{array}$ & $\mathrm{HNC}^{\alpha}{ }_{\mathrm{H}}$ & $\begin{array}{l}0.007 \\
7.834\end{array}$ & $\begin{array}{l}0.0 \\
7.7\end{array}$ & 7.848 & 7.7 & $\begin{array}{l}0.908 \\
7.997\end{array}$ & 9.6 & $\begin{array}{l}0.883 \\
7.975\end{array}$ & 8.8 & $\begin{array}{l}0.892 \\
7.833\end{array}$ & 8.8 \\
\hline & $\mathrm{HC}^{\alpha}$ & $\mathrm{HC}^{\alpha} \mathrm{C}^{\beta} \mathrm{H}^{\prime}$ & 4.917 & 7.1 & 4.956 & 71 & 5.192 & 123 & 5.111 & 12.8 & 4.952 & 13.0 \\
\hline & $\mathrm{H}^{\prime} \mathrm{C}^{\beta}$ & $\mathrm{H}^{\prime} \mathrm{C}^{\beta} \mathrm{H}^{\prime \prime}$ & 3.198 & 14.8 & 3.240 & 14.8 & 3.833 & 15.3 & 3.375 & 15.4 & 3.236 & 12.8 \\
\hline & $\mathrm{H}^{\prime \prime} \mathrm{C}^{\beta}$ & $\mathrm{HC}^{\alpha} \mathrm{C}^{\beta} \mathrm{H}^{\prime \prime}$ & 2.739 & 12.6 & 2.761 & 12.3 & 3.011 & 6.6 & 3.127 & 6.0 & 2.979 & 6.6 \\
\hline & $\mathrm{H}-4^{\prime}$ & & 7.428 & & 7.530 & & 7.603 & & 7.633 & & 7.436 & \\
\hline & $\mathrm{H}-5^{\prime}$ & & 6.594 & & 6.730 & & 6.797 & & 6.828 & & 6.675 & \\
\hline & $\mathrm{H}-7^{\prime}$ & & 6.747 & & 6.850 & & 6.800 & & 6.867 & & 6.722 & \\
\hline & $\mathrm{HN}^{\text {ind ol }}$ & & 11.181 & & 11.400 & & 11.564 & & 11.614 & & 10.958 & \\
\hline & $\mathrm{OCH}_{3}$ & & $9.119^{a}$ & & 3.770 & & 3.786 & & 3.786 & & 3.756 & \\
\hline \multirow[t]{3}{*}{$\mathrm{Gly}^{5}$} & $\mathrm{HN}^{3}$ & $\mathrm{HNC}^{\alpha} \mathrm{H}^{\prime}$ & 7.943 & 9.3 & 7.944 & 8.8 & 7.665 & 8.8 & 7.890 & 9.4 & 8.047 & 7.3 \\
\hline & $\mathrm{H}^{\prime} \mathrm{C}^{\alpha}$ & $\mathrm{H}^{\prime} \mathrm{C}^{\alpha} \mathrm{H}^{\prime \prime}$ & 4.306 & & 4.278 & & 4.250 & 17.6 & 4.311 & 18.0 & 4.166 & 18.7 \\
\hline & $\mathrm{H}^{\prime \prime} \mathrm{C}^{\beta}$ & $\mathrm{HNC}^{\alpha} \mathrm{H}^{\prime \prime}$ & 3.389 & 0 & 3.361 & 0 & 3.223 & 0 & 3.333 & 0 & 3.444 & 0 \\
\hline \multirow[t]{7}{*}{$\mathrm{Ile}^{6}$} & $\mathrm{HN}$ & $\mathrm{HNC}^{\alpha} \mathrm{H}$ & 8.443 & 3.3 & 8.437 & 3.3 & 8.107 & 4.4 & 8.369 & 3.3 & 8.442 & 4.4 \\
\hline & $\mathrm{HC}^{\alpha}$ & $\mathrm{HC}^{\alpha} \mathrm{C}^{\beta} \mathrm{H}$ & 3.665 & 7.7 & 3.664 & 7.7 & 3.750 & 7.7 & 3.678 & 8.0 & 3.708 & 8.8 \\
\hline & $\mathrm{HC}^{\beta}$ & & 1.556 & & 1.556 & & 1.556 & & 1.556 & & 1.556 & \\
\hline & $\mathrm{H}^{\prime} \mathrm{C}^{\gamma}$ & & 1.500 & & 1.526 & & 1.486 & & 1.528 & & 1.528 & \\
\hline & $\mathrm{H}^{\prime \prime} \mathrm{C}^{\gamma}$ & & 1.111 & & 1.100 & & 1.111 & & 1.111 & & 1.111 & \\
\hline & $\mathrm{CH}_{3}^{\beta}$ & & 0.797 & & 0.795 & & 0.806 & & 0.799 & & 0.792 & \\
\hline & $\mathrm{CH}_{3}^{3} \gamma$ & & 0.825 & & 0.822 & & 0.819 & & 0.826 & & 0.825 & \\
\hline \multirow[t]{3}{*}{$\mathrm{Gly}^{7}$} & $\mathrm{HN}^{3}$ & $\mathrm{HNC}^{\alpha} \mathrm{H}^{\prime}$ & 8.691 & 7.4 & 8.688 & 7.1 & 8.851 & 6.6 & 8.749 & 6.5 & 8.769 & 7.7 \\
\hline & $\mathrm{H}^{\prime} \mathrm{C}^{\alpha}$ & $\mathrm{H}^{\prime} \mathrm{C}^{\alpha} \mathrm{H}^{\prime \prime}$ & 3.904 & 17.6 & 3.907 & 17.1 & 3.764 & 17.0 & 3.874 & 17.0 & 3.911 & 17.6 \\
\hline & $\mathrm{H}^{\prime \prime} \mathrm{C}^{\alpha}$ & $\mathrm{HNC}^{\alpha} \mathrm{H}^{\prime \prime}$ & 3.444 & 5.0 & 3.444 & 5.0 & 3.516 & 5.5 & 3.458 & 5.0 & 3.417 & 5.0 \\
\hline \multirow[t]{4}{*}{$\mathrm{Cys} \mathrm{s}^{8}$} & $\mathrm{HN}$ & $\mathrm{HNC}^{\alpha} \mathrm{H}$ & 8.250 & 10.0 & 8.259 & 9.9 & 7.972 & 9.4 & 8.159 & 9.9 & 7.938 & 9.9 \\
\hline & $\mathrm{HC}^{\alpha}$ & $\mathrm{HC}^{\alpha} \mathrm{C}^{\beta} \mathrm{H}^{\prime}$ & 4.944 & 13.2 & 4.956 & 13.2 & 4.993 & 8.2 & 5.094 & 12.1 & 4.568 & 11.6 \\
\hline & $\mathrm{H}^{\prime} \mathrm{C}^{\beta}$ & $\mathrm{H}^{\prime} \mathrm{C}^{\beta} \mathrm{H}^{\prime \prime}$ & 3.081 & 13.2 & 3.091 & 13.2 & 4.533 & 14.3 & 4.000 & 14.3 & 3.050 & 10.5 \\
\hline & $\mathrm{H}^{\prime \prime} \mathrm{C}^{\beta}$ & $\mathrm{HC}^{\alpha} \mathrm{C}^{\beta} \mathrm{H}^{\prime \prime}$ & 2.958 & & 2.994 & 4.4 & 2.499 & 1.0 & 2.820 & 0 & 2.774 & 3.3 \\
\hline
\end{tabular}

distinction was achieved by NOE experiments. According to the data on the crystal structure of $\mathbf{4}$, there is a short distance $(2.455 \AA)$ between Ile $\mathrm{H}^{\mathrm{N}}$ and one of the $\mathrm{Gly}^{5} \mathrm{H}^{\alpha}$ atoms. The NOE difference spectrum obtained by irradiation of that Ile $\mathrm{H}^{\mathrm{N}}$ yielded a strong negative NOE doublet of doublets (Figure 5i) at frequencies exactly coinciding with those obtained by the SDDS measurement for one of the two Gly $\mathrm{H}^{\alpha}$ 's (Figure $5 \mathrm{~h})$. The spin system of $\mathrm{Gly}^{5}$ is thus unequivocally identified. Independently, the signals of $\mathrm{Gly}^{7}$ were identified by irradiating its $\mathrm{H}^{\mathrm{N}}$ and observing a NOE signal of $\mathrm{Ile}^{6} \mathrm{H}^{\mathrm{N}}$, the distance between those two protons amounting to $2.157 \AA$.

All signals of the remaining spin systems of hydroxyproline, $\gamma, \delta$-dihydroxyisoleucine, and isoleucine have been unambiguously assigned by consecutive decoupling experiments, partly in the SDDS mode in cases of signal overlap.

Although a NOE signal of $\operatorname{Trp~} \mathrm{H}^{\alpha}$ of $6^{\prime}-O-\mathrm{Me}-\alpha$-ama $(R)$-sulfoxide (3) was obtained in the same manner as it was done for 4 (Figure $6 \mathrm{~b}, \mathrm{c}$ ), this was not sufficient to assign the $\mathrm{H}^{\mathrm{N}}, \mathrm{H}^{\prime \beta}$, and $\mathrm{H}^{\prime \prime \beta}$ signals of tryptophan because this $\mathrm{H}^{\alpha}$ resonance overlaps with that of cysteine (Figure 6a). This difficulty was overcome by the help of spin-decoupled NOE difference spectra (Richarz \& Wüthrich, 1978). Simultaneous decoupling from the assumed $\operatorname{Trp~} \mathrm{H}^{\mathrm{N}}$ during the acquisition of the Trp $\mathrm{H}^{\alpha}$ NOE difference signal, demonstrated the connectivity between these two resonances (Figure 6d). The connectivities with $\operatorname{Trp} \mathrm{H}^{\prime \beta}$ and $\mathrm{H}^{\prime \prime \beta}$ were established in a similar way (Figure 6e). The assignments of all other signals of $(R)$-sulfoxide 3 were made analogously as described for $(S)$-sulfoxide 4. The same approach was applied to $\alpha$-amanitin 2 , the sulfone 5 , and thioether 6 . So that information on intramolecular hydrogen bonds could be obtained, the exchange rates of the amide protons of 4 , as well as the temperature coefficients of their chemical shifts, have been determined. They are presented in Table III along with those obtained previously for $\alpha$-amanitin (Tonelli et al., 1978) and shown here for comparison.

\section{Discussion}

Of the several modifications of the Karplus equation suited for the calculation of the torsion angle $\phi$ in the $\mathrm{HNC}^{\alpha} \mathrm{H}$ 
Table III: Exchange Rates (on Addition of $5 \%{ }^{2} \mathrm{H}_{2} \mathrm{O}$ ) and

Temperature Coefficients of the Peptide Protons of Compounds $2^{a}$ and 4 in $\mathrm{Me}_{2} \mathrm{SO}-d_{6}$ at $23^{\circ} \mathrm{C}$

\begin{tabular}{|c|c|c|c|c|c|c|}
\hline \multirow[b]{2}{*}{$\begin{array}{c}\text { amino } \\
\text { acid }\end{array}$} & \multicolumn{3}{|c|}{ compound 2} & \multicolumn{3}{|c|}{ compound 4} \\
\hline & $\underset{(\mathrm{ppm})}{\mathrm{H}^{\mathrm{N}}}$ & $\begin{array}{l}\text { temp } \\
\text { coeff } \\
(\mathrm{ppm} / \\
\left.{ }^{\circ} \mathrm{C}\right)\end{array}$ & $\begin{array}{l}t_{1 / 2}^{b} \\
(\min )\end{array}$ & $\begin{array}{c}\mathrm{H}^{\mathrm{N}} \\
(\mathrm{ppm})\end{array}$ & $\begin{array}{l}\text { temp } \\
\text { coeff } \\
(\mathrm{ppm} / \\
\left.{ }_{\circ}^{\circ} \mathrm{C}\right)\end{array}$ & $\begin{array}{l}t_{1 / 2}^{b} \\
(\mathrm{~min})\end{array}$ \\
\hline $\mathrm{Asn}^{1}$ & 8.411 & 0.0023 & 50 & 8.754 & 0.0016 & 8 \\
\hline $\mathrm{Hyi}^{3}$ & 7.775 & 0.0016 & 30 & 7.967 & 0.0024 & 10 \\
\hline$T_{r p}^{4}$ & 7.834 & 0.0032 & 40 & 7.997 & 0.0010 & 10 \\
\hline Gly $^{5}$ & 7.943 & 0.0023 & $c$ & 7.665 & 0.0018 & $d$ \\
\hline $11 e^{6}$ & 8.443 & 0.0044 & 3 & 8.107 & 0.0043 & 47 \\
\hline Gly? & 8.691 & 0.0040 & 25 & 8.851 & 0.0050 & 17 \\
\hline $\mathrm{Cys}^{8}$ & 8.250 & 0.0031 & 200 & 7.972 & 0.0027 & 17 \\
\hline ta & & 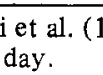 & & & & \\
\hline
\end{tabular}

fragments of peptides (Bystrov, 1976), we applied that proposed by Bystrov et al. (1969):

$$
{ }^{3} J_{\mathrm{HNC}^{\alpha} \mathrm{H}}=9.4 \cos ^{2} \theta-1.1 \cos \theta+0.4
$$

which has found wide acceptance. The coupling constants used for these calculations have been corrected for electronegativity effects according to the equation ${ }^{3} J_{\mathrm{HNCOH}}=1.09^{3} J_{\text {obsd }}$ (Bystrov, 1976).

The $\chi$ angles were calculated by using the equation derived "from observations of substances as like amino acid residues as possible in substitution and bond angle" (Kopple et al., 1973):

$$
{ }^{3} J_{\mathrm{HC}^{\alpha} \mathrm{C}^{\beta} \mathrm{H}}=9.4 \cos ^{2} \theta-1.4 \cos \theta+1.6
$$

Since the $\theta$ values used by Kopple et al. in this fit were rather evenly distributed between $0^{\circ}$ and $180^{\circ}$, eq 2 can be considered representative of peptides without further corrections for electronegativities of the substituents and their orientation.

Equation 1 yields two values of the dihedral angle $\theta$ for ${ }^{3} \mathrm{~J}$ $<8.7 \mathrm{~Hz}$ and so does eq 2 for ${ }^{3} J<9.6 \mathrm{~Hz}$. Since $\phi$ can be either positive or negative, up to four different torsional angles $\phi$ (or $\chi$ ) can be expected. This number is doubled when the assignments of $\delta\left(\mathrm{H}^{\prime \beta}\right)$ and $\delta\left(\mathrm{H}^{\prime \prime \beta}\right)$ [or $\delta\left(\mathrm{H}^{\prime \alpha}\right)$ and $\delta\left(\mathrm{H}^{\prime \alpha}\right)$ for glycine residues] are merely relative. This leads to a very large number of theoretically possible conformations for amanitins, which have seven $\phi$ and two bridge $\chi$ angles. The search for low-energy conformations could be performed by computations (Tonelli et al., 1978). However, reference to the crystal structure, which is a real minimum-energy conformation, seems more reliable despite some uncertainties arising from the additional lattice energy term on the one hand and the solvation energy term on the other hand. Indeed, the lattice energy is hardly essential here, because of the lack of strong intermolecular contacts; the solvation energy is unlikely to outweigh the restraints imposed by the intramolecular forces in cases of bridged, semirigid structure fragments. The X-ray structures of the sulfoxide 4 and sulfone 5 were obtained in the present work. The structure of $\beta$-amanitin (1) (Kostansek et al., 1978) can be used for comparison with the NMR data on the sulfoxide 3 which differs in inessential structure details only.

The results, gathered in Table IV, show that for each of the substances 3-5 the majority of torsion angles $\phi$ and $\chi$ coincide, within experimental error, with those determined by X-ray analysis. $\phi$ angles differ significantly only for Hyi and Trp. Both of these amino acid residues are hydrogen bonded to the oxygen of the conformationally labile side chain of Asn. Hence, it is understandable that the competing strong proton acceptor, dimethyl sulfoxide, exerts some influence on this structure fragment. However, the differences are small $\left(19-23^{\circ}\right)$ and do not seem to change substantially the overall shape. The same can be said with even more grounds about the $x$ angles. The large differences of $33-48^{\circ}$ refer to the side chains of Hyi and Ile, which are located at the periphery of the molecule and can rotate rather freely. At the same time, the corresponding differences for the side chains of Trp and Cys forming the bicyclic bridge are very small. However, there is one exception: the difference for Cys of 5 amounts to $27^{\circ}$. This value is somewhat uncertain owing to the unpredictability of the effect of the two electronegative $\mathrm{S}-\mathrm{O}$ bonds on the $\mathrm{HC}^{\alpha} \mathrm{C}^{\beta} \mathrm{H}$ coupling constant.

The NMR data on the intramolecular hydrogen bonds also suggest a similarity of the solution structure of amatoxins to their crystal structure. The occurrence of such bonds is believed to be reflected by low H/D exchange rates and small temperature coefficients of the chemical shifts of hydrogenbonded protons (Deslauriers \& Smith, 1980). All five hy-

Table IV: Comparison of the $\phi$ and $x$ Rotation Angles for Amatoxins 3-6, As Derived from Vicinal Coupling Constants, with Those

\begin{tabular}{|c|c|c|c|c|c|c|c|c|c|}
\hline substance & angle & method & $A \operatorname{sn}^{1}$ & $\mathrm{Hyi}^{3}$ & $\operatorname{Trp}^{4}$ & Gly $^{5}$ & $\mathrm{Ile}^{6}$ & $\mathrm{Gly}^{7}$ & $\mathrm{Cys}^{8}$ \\
\hline 3 & $\phi$ & $\begin{array}{l}\text { X-ray }{ }^{a} \\
\text { NMR } \\
\text { X-ray } \\
\text { NMR }\end{array}$ & $\begin{array}{r}-172 \\
-174 \\
61 \\
63^{d}\end{array}$ & $\begin{array}{r}-79 \\
-106 \\
-145 \\
-106\end{array}$ & $\begin{array}{r}-109 \\
-90 \\
167 \\
164^{e}\end{array}$ & $\begin{array}{l}140 \\
146^{b}\end{array}$ & $\begin{array}{r}-59 \\
-62 \\
-66 \\
-103\end{array}$ & $\begin{array}{l}87 \\
92^{c}\end{array}$ & $\begin{array}{c}-121 \\
-126 \\
-174 \\
176^{f}\end{array}$ \\
\hline 4 & $\phi$ & $\begin{array}{l}\text { X-ray } \\
\text { NMR } \\
\text { X-ray } \\
\text { NMR }\end{array}$ & $\begin{array}{r}-68 \\
-76 \\
66 \\
74\end{array}$ & $\begin{array}{r}-67 \\
-90 \\
-79 \\
-127\end{array}$ & $\begin{array}{r}-81 \\
-108 \\
173 \\
168^{j}\end{array}$ & $\begin{array}{l}158 \\
146^{g}\end{array}$ & $\begin{array}{r}-63 \\
-69 \\
-63 \\
-103\end{array}$ & $\begin{array}{l}80 \\
80^{h}\end{array}$ & $\begin{array}{l}-122 \\
-134 \\
-139 \\
-145^{k}\end{array}$ \\
\hline 5 & $\phi$ & $\begin{array}{l}\text { X-ray } \\
\text { NMR } \\
\text { X-ray } \\
\text { NMR }\end{array}$ & $\begin{array}{c}-67 \\
-65 \\
69 \\
64^{n}\end{array}$ & $\begin{array}{r}-66 \\
-99 \\
-82 \\
-115\end{array}$ & $\begin{array}{l}-80 \\
-99 \\
171 \\
170^{\circ}\end{array}$ & $\begin{array}{l}159 \\
143^{l}\end{array}$ & $\begin{array}{r}-62 \\
-62 \\
-59 \\
-100\end{array}$ & $\begin{array}{l}80 \\
81^{m}\end{array}$ & $\begin{array}{l}-121 \\
-126 \\
-143 \\
-170^{p}\end{array}$ \\
\hline 6 & $\begin{array}{l}\phi \\
x\end{array}$ & $\begin{array}{l}\text { NMR } \\
\text { NMR }\end{array}$ & $\begin{array}{r}-175 \\
62^{s}\end{array}$ & $\begin{array}{l}-105 \\
-114\end{array}$ & $\begin{array}{l}-99 \\
168^{t}\end{array}$ & $152^{q}$ & $\begin{array}{l}-69 \\
-96\end{array}$ & $94^{r}$ & $\begin{array}{l}-126 \\
-172^{u}\end{array}$ \\
\hline
\end{tabular}
Determined by X-ray Analysis

${ }^{a}$ The X-ray structure of $\beta$-amanitin (1) has been used for comparison with $3 .{ }^{b}$ Average of the two values, $142^{\circ}$ and $150^{\circ}$, obtained from ${ }^{3} J_{\mathrm{HNC}}{ }^{\alpha} \mathrm{H}^{\prime}$ and ${ }^{3} J_{\mathrm{HNC}}{ }^{\alpha} \mathrm{H}^{\prime \prime}$, respectively. ${ }^{c}$ As in footnote $b, 87^{\circ}$ and $97^{\circ}$. ${ }^{d}$ Average of $60^{\circ}$ and $66^{\circ}$, obtained from ${ }^{3} J_{\mathrm{HC}} \mathrm{C}^{\alpha} \mathrm{C}^{\beta} \mathrm{H}^{\prime}$ and ${ }^{3} J_{\mathrm{H} \mathrm{C}}{ }^{\alpha} \mathrm{C}^{\beta} \mathrm{H}^{\prime \prime}$, respectively. $e$ As in footnote $d, 152^{\circ}$ and $175^{\circ}$. $f$ As in footnote $d, 180^{\circ}$ and $171^{\circ}$. $g$ as in footnote $b, 150^{\circ}$ and $141^{\circ}$

$h$ As in footnote $b, 76^{\circ}$ and $84^{\circ}$. $i$ As in footnote $d, 51^{\circ}$ and $96^{\circ} .{ }^{j}$ As in footnote $d, 180^{\circ}$ and $156^{\circ}$. ${ }^{k}$ As in footnote $d,-140^{\circ}$ and $-150^{\circ}$. $l$ As in footnote $b, 150^{\circ}$ and $135^{\circ}$. $m$ As in footnote $b, 85^{\circ}$ and $77^{\circ}$. $n$ As in footnote $d, 55^{\circ}$ and $73^{\circ}$. $0^{\circ}$ As in footnote $d, 180^{\circ}$ and $160^{\circ}$.

$p$ As in footnote $d,+170^{\circ}$ and $-150^{\circ}$. ${ }^{\circ}$ As in footnote $b, 153^{\circ}$ and $150^{\circ}$. $r$ As in footnote $b, 90^{\circ}$ and $97^{\circ}$. ${ }^{s}$ As in footnote $d, 55^{\circ}$ and $69^{\circ}$. ${ }^{t}$ As in footnote $d, 180^{\circ}$ and $155^{\circ}$, ${ }^{u}$ As in footnote $d,-164^{\circ}$ and $-180^{\circ}$. 
Table V: Relationship between the Chemical Nature of the Cross-Link, the Magnitude of the Inhibitory Constant $K_{i}$ on DNA-Dependent RNA Polymerase II (or B) from Calf Thymus, and Toxicity of the Amatoxin Derivatives 2-6 ${ }^{a}$

\begin{tabular}{ccccc}
\hline compound & $\begin{array}{c}\text { coss-link } \\
\text { position } \\
\text { of oxygen } \\
(S R)\end{array}$ & $\begin{array}{c}\text { minus } \\
\text { charge on } \\
\text { oxygen }(S)\end{array}$ & $\begin{array}{c}K_{\mathrm{i}} \\
(\mathrm{nM})\end{array}$ & toxicity $b$ \\
\hline 2,3 & -S-O & & 2.6 & 0.3 \\
4 & O-S- & strong & 20.0 & 25.0 \\
5 & O-S-O & weak & 5.7 & 0.5 \\
6 & -S- & & 2.5 & 0.25 \\
\hline
\end{tabular}

${ }^{a}$ From Wieland et al. (1981). ${ }^{b}$ Dose in milligrams per kilograin of body weight causing death of $50 \%$ of the experimental animals (white mice) $=\mathrm{LD}_{\mathrm{s} 0}$.

drogen bonds shorter than $3 \AA$, found in the crystal structure, exhibit temperature coefficients smaller than $-3 \times 10^{-3}$ (Table III, items 1-4 and 7); these coefficients are considered as a good criterion for intramolecular hydrogen bonds (Deslauriers \& Smith, 1980). One of those bonds, that between Gly ${ }^{5} \mathrm{NH}$ and $\mathrm{Asn}^{1} \mathrm{O}=\mathrm{C}$, is special because its $\mathrm{NH} / \mathrm{ND}$ exchange rate is smaller by 2 orders of magnitude than that for all other $\mathrm{H}$ bonds (Table III, item 4). The $\mathrm{Gly}^{5}$ peptide proton is located inside of a "cage" shaped by several neighboring fragments which are visible in Figure 2.

Thus, it follows from the NMR data that the conformation of the amanitin derivatives $3-5$ is practically the same in solution and in the crystalline state. As for the deoxo derivative 6, for which the crystal structure was not determined, a comparison with the sulfoxide $3(R)$ seems best suited since both these substances lack the $\mathrm{S}-\mathrm{O}$ bond directed toward $\mathrm{NH}$ of asparagine (as described above in the discussion of the crystal structure). The congruence is nearly perfect. Hence, the above conclusions concerning the similarity of the crystal and solution structures seems to apply to 6 as well.

The toxicity values $\left(\mathrm{LD}_{50}\right.$ in $\mathrm{mg} / \mathrm{kg}$ of white mouse) of $(R)$-sulfoxide 3 , sulfone 5 , and $(S)$-sulfoxide 4 are $0.3,0.5$, and 25.0 , respectively. Now that it has been found that the three-dimensional structures of the slightly toxic $(S)$-sulfoxide 4 , the considerably toxic sulfone 5 , and the markedly toxic $(R)$-sulfoxide 3 are practically identical not only in the crystalline state but also in $\mathrm{Me}_{2} \mathrm{SO}$ solution, an explanation other than different conformations is necessary. We cannot yet exclude a difference when water, rather than $\mathrm{Me}_{2} \mathrm{SO}$, is the solvent. However, such a difference seems improbable. If, then, we compare compound 4 with compound 3 and 5 , the detailed stereochemistry of the oxygenated sulfur shows that the oxygen of the $(S)$-sulfoxide 4 is oriented toward the interior of the peptide molecule and that it forms an intramolecular hydrogen bond with the peptide bond NH of asparagine. On the other hand, the oxygen in the $R$ configuration at the sulfur in $\mathbf{3}$ and $\mathbf{5}$ is oriented toward the exterior of the molecule and is free of intramolecular contacts. This $R$ oxygen, then, is a candidate for inhibitory binding to the enzyme. If altered binding of the inhibitor requires bonding to the oxygen of the $S$ configuration and absence of the oxygen of the $R$ configuration, the less toxic effects of $\mathbf{4}$ are not necessarily inconsistent with the strong inhibitory capacity of the oxygen-free $O$ Me- $\alpha$-ama sulfide 6. This effect could arise if a group of the protein could form a hydrogen bond to either the $R$ or $S$ oxygen, possibly involving local changes in conformation in the inhibitors. However, other explanations such as those involving the orientation of S-O dipoles (Wieland et al., 1980) are plausible and indeed are related to the tentative explanation given above. It suggests that in the weaker binding $(S)$ sulfoxide 4 the strong negative charge of the $\mathrm{S}-\mathrm{O}$ dipole comes close to a (rejecting) negative charge at the binding site of the protein whereas in the $(R)$-sulfoxide 3 the dipole, pointing in the opposite direction, would not interfere with that negatively charged side chain. The sulfone group, OSO, also possesses some dipole character, although much smaller than the sulfoxide. This might account for the slightly weakened affinity (and toxicity) of sulfone 5 to the RNA polymerase (see Table V).

Another, although related, explanation for the difference in binding of the different derivatives might arise from the slight conformational difference in the Asn ${ }^{1}-\mathrm{Cys}^{8}$ peptide bond (Table IV). In the two cases where the $S$ oxygen is present, $(S)$-sulfoxide (4) and sulfone (5), this oxygen is hydrogen bonded to the Asn ${ }^{1} \mathrm{NH}$ group causing a rotation of the plane of the peptide bond of $90-105^{\circ}$ from the orientation that it occupies when the $S$ oxygen is absent, $\beta$-amanitin (1) and sulfide (6). It is possible that the $\mathrm{Cys}^{8}$ carbonyl group, rather than the sulfur bridge, forms this one important additional binding to a certain group in the protein. This carbonyl group may not be in the correct orientation for binding when the peptide bond is tilted $90^{\circ}$ as the hydrogen bond, mentioned above, is formed. In the sulfone (5), however, this important contact might be partially compensated for by a similar hydrogen bond to the $R$ oxygen which points generally in the same direction as the untilted carbonyl group and is only about $3.8 \AA$ away. Again binding in a somewhat shifted position in the enzyme may occur.

Some relationships between the nature of the sulfur bridge on the magnitude of the inhibitory constant $K_{\mathrm{i}}$ on DNA-dependent RNA polymerase II (or B) from calf thymus are given in Table $\mathrm{V}$.

In the paper of Wieland et al. (1981) from which the data in Table $V$ have been taken, it has also been noted that the difference between inhibitory constants of RNA polymerase of thioether and $(R)$-sulfoxide (higher affinity) and $(S)$ sulfoxide (lower affinity) is also valid for synthetic, although biologically less active analogues of amaninamide. Although a unified explanation based on the direction of a local dipole, the direction of the cysteine carbonyl bond, and related effects can be given, it surely may be necessary to examine the structure of enzyme-inhibitor complexes in order to understand these results more fully.

\section{Supplementary Material Available}

Fractional coordinates (Table S1), bond distances (Table S2), bond angles (Table S3), and dihedral angles (Table S4) of sulfone $\mathbf{5}$ in the crystallographic structure, fractional coordinates (Table S5), bond distances (Table S6), bond angles (Table S7), and dihedral angles (Table S8) of sulfoxide 4 in the crystallographic structure, and a numbering scheme for these tables (Figure $\mathrm{S} 1$ ) (7 pages). Ordering information is given on any current masthead page.

Registry No. 1, 21150-22-1; 2, 23109-05-9; 3, 21150-19-6; 4, 55399-91-2; 5, 55325-99-0; 6, 23651-02-7.

\section{References}

Buckingham, A. D. (1960) Can. J. Chem. 38, 300.

Buku, A., Altmann, R., \& Wieland, Th. (1974) Liebigs Ann. Chem., 1580.

Bystrov, V. F. (1976) Prog. Nucl. Magn. Reson. Spectrosc. 10,41 .

Bystrov, V. F., Portnova, S. L., Tsetlin, V. I., Ivanov, V. T., \& Ovchinnikov, Yu. A. (1969) Tetrahedron 25, 493.

Deslauriers, R., \& Smith, J. C. P. (1980) Biological Magnetic Resonance (Berliner, L. J., \& Reuben, J., Eds.) Vol. 2, pp 243-344, Plenum Press, New York. 
Ernst, R. R. (1966) Adv. Magn. Reson. 2, 60.

Faulstich, H., Wieland, Th., \& Jochum, Ch. (1968) Liebigs Ann. Chem. 713, 186.

Gibbons, W. A., Beyer, C. F., Dadok, J., Speicher, R. F., \& Wyssbrod, H. R. (1975) Biochemistry 14, 420.

Kabsch, W. (1976) Acta Crystallogr., Sect. A A32, 922.

Kabsch, W. (1978) Acta Crystallogr., Sect. A A34, 827.

Kopple, K. D., Wiley, G. R., \& Tauke, R. (1973) Biopolymers 12, 627 .

Kostansek, E. C., Lipscomb, W. N., Yocum, R. R., \& Thiessen, W. E. (1977) J. Am. Chem. Soc. 99, 1273.

Kostansek, E. C., Lipscomb, W. N., Yocum, R. R., \& Thiessen, W. E. (1978) Biochemistry 17, 3790.

Main, P., Hull, S. E., Lessinger, L., Germain, G., Declercq, J. P., \& Woolfson, H. M. (1978) MULTan-78: A System

of Computer Programs for the Automatic Solution of Crystal Structures from X-Ray Diffraction Data, Universities of York and Louvain.

McConnell, H. (1957) J. Chem. Phys. 27, 226.
Nuzzo, R. W., Simon, M. J., \& San Filippo, J. H. (1977) J. Org. Chem. 42, 568.

Richarz, R., \& Wüthrich, K. (1978) J. Magn. Reson. 30, 147.

Sheldrick, G. (1975) Programs for Crystal Structure Determination, Cambridge University Press, Cambridge, England.

Tonelli, A. E., Patel, D. J., Wieland, Th., \& Faulstich, H. (1978) Biopolymers 17, 1973.

Wagner, G., \& Wüthrich, K. (1979) J. Magn. Reson. 33, 657.

Wieland, H., Hallermayer, R., \& Zilg, W. (1941) Liebigs Ann. Chem. 548, 1.

Wieland, Th., \& Boehringer, W. (1960) Liebigs Ann. Chem. $635,178$.

Wieland, Th., \& Faulstich, H. (1978) CRC Crit. Rev. Biochem. 5,185 .

Wieland, Th., Wirth, L., \& Fischer, E. (1949) Liebigs Ann. Chem. 564, 152.

Wieland, Th., Götzendörfer, Ch., Zanotti, G., \& Vaisius, A. C. (1981) Eur. J. Biochem. 117, 161.

\title{
Modulation of Tubulin-Nucleotide Interactions by Microtubule-Associated Proteins: Polymerization with Ribose-Modified Analogues of Guanosine 5'-Triphosphate ${ }^{\dagger}$
}

\author{
Ernest Hamel, ${ }^{*}$ Anthony A. del Campo, Jay Lustbader, and Chii M. Lin
}

ABSTRACT: We have examined the ability of a series of ribose-modified analogues of GTP to support microtubule-associated protein (MAP)-dependent polymerization of purified tubulin in $0.1 \mathrm{M} 2-(N$-morpholino)ethanesulfonate $-0.5 \mathrm{mM}$ $\mathrm{MgCl}_{2}$. Both the tubulin and the MAPs were free of $\mathrm{nu}-$ cleosidediphosphate kinase activity. Deoxyguanosine 5'-triphosphate analogues and arabinosylguanosine 5 -triphosphate all supported polymerization reactions in which microtubules were formed and which began earlier, were more extensive, and required a lower nucleotide concentration than the GTP-supported reaction. One of these nucleotides, $2^{\prime}, 3^{\prime}$-dideoxyguanosine $5^{\prime}$-triphosphate (ddGTP), was unique in also supporting polymerization without MAPs, although a higher nucleotide concentration was required and the polymer was a mixture of microtubules and open sheets. The microtubules formed with ddGTP plus MAPs were significantly more cold stable than microtubules formed with GTP plus MAPs, while the polymer formed with ddGTP minus MAPs had similar cold lability to the GTP-dependent tubules. Analogues with an open ribose ring or bearing a methyl or phosphate group at the $2^{\prime}$ - or $3^{\prime}$-hydroxyl were also examined. While $2^{\prime}-O$ -

G uanosine nucleotides are intimately involved in the structure and function of tubulin, the major component of the mitotic spindle. The protein binds 2 molar equiv of nucleotide

${ }^{\dagger}$ From the Laboratory of Medicinal Chemistry and Biology (E.H., J.L., and C.M.L.) and the Laboratory of Experimental Therapeutics and Metabolism (A.A.d.C.), Developmental Therapeutics Program, Division of Cancer Treatment, National Cancer Institute, National Institutes of Health, Bethesda, Maryland 20205. Received July 23, 1982; revised manuscript received October $5,1982$. methylguanosine 5'-triphosphate (2'OMeGTP) seemed comparable to GTP in its ability to support MAP-dependent polymerization as a function of nucleotide concentration, progressively decreasing activity was observed with acycloguanosine 5'-triphosphate (acyclo-GTP), 3'-O-methylguanosine $5^{\prime}$-triphosphate ( $3^{\prime} \mathrm{OMeGTP}$ ), and the periodate-oxidized, borohydride-reduced derivative of GTP (ox-red-GTP). The guanosine tetraphosphates had little or no ability to support tubulin polymerization with MAPs. Microtubules were formed only with acyclo-GTP, while the polymer formed with $3^{\prime}$ OMeGTP was a mixture of microtubules and open sheets. The structures formed with $2^{\prime} \mathrm{OMeGTP}$ and ox-red-GTP were thick-walled, relatively short, enlarged tubules about $82 \mathrm{~nm}$ in diameter. No definite protofilaments could be distinguished in these bizarre structures. If nucleosidediphosphate kinase was included in the reaction mixture, however, microtubules became the predominant product with ox-red-GTP. Moreover, 2'OMeGTP and ox-red-GTP, as well as GTP, supported microtubule formation from purified tubulin (in the absence of MAPs) in the presence of $3.4 \mathrm{M}$ glycerol-6 $\mathrm{mM} \mathrm{MgCl}_{2}$.

(Weisenberg et al., 1968; Bryan, 1972; Kobayashi, 1974; Hamel \& Lin, 1981a). Half cannot be exchanged with free GTP and can only be removed from the protein by its denaturation (the nonexchangeable GTP). The other half can be exchanged with free GDP or GTP and can also be removed from tubulin with difficulty (the exchangeable GTP). Tubulin polymerization is usually associated with hydrolysis of exchangeably bound GTP (Kobayashi, 1975; Weisenberg et al., 1976; Penningroth \& Kirschner, 1977; Arai \& Kaziro, 1977; 